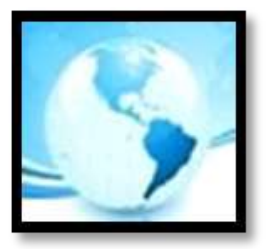

MALAYSIAN ONLINE JOURNAL OF

EDUCATIONAL MANAGEMENT

(MOJEM)

January 2020, VOLUME 8, ISSUE 1, 58-81

E-ISSN NO: $2289-4489$

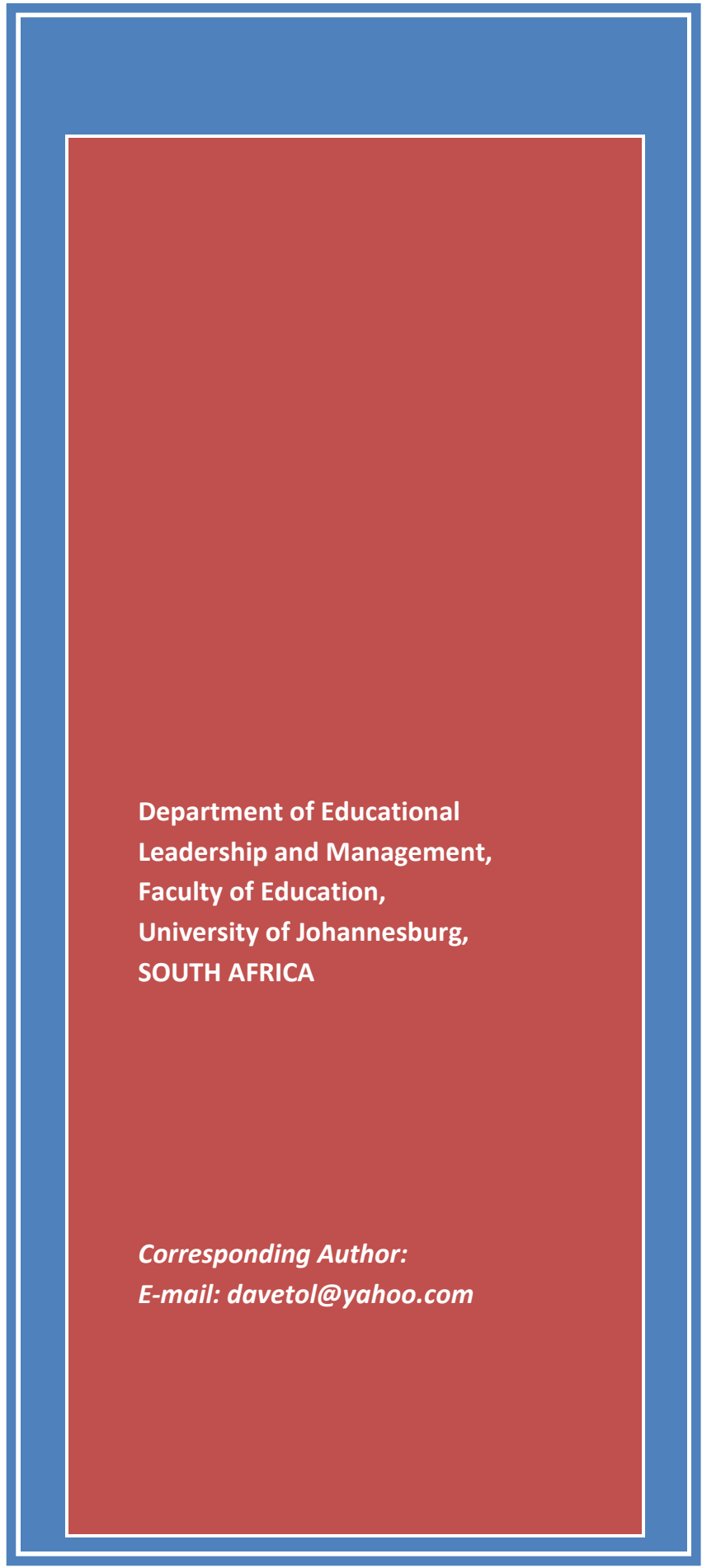

\title{
AN INVESTIGATION INTO ISSUES IMPEDING HIGHER EDUCATION EFFECTIVENESS IN PUBLIC UNIVERSITIES
}

David Jimoh Kayode (PhD) \& Suraiya Rathankoomar Naicker (PhD)

\begin{abstract}
The effectiveness of public universities in Nigeria has continued to generate discussion and is a matter of urgent attention in achieving the mission and vision of the higher education system. This study was carried out to investigate the issues obstructing the effectiveness of public universities in Nigeria. The conceptual framework was adapted from the European Foundation for Quality Management Excellence model (EFQM). This study adopted a generic qualitative design to collect data through semi-structured interviews from eight participants, including the deputy vice-chancellor, deans, head of departments, and lecturers that were purposively selected. Data collected were analysed using thematic analysis with Nvivo (version 10). The findings of the study revealed that leadership, academic and administrative issues, contextual issues and funding are the major factors affecting the effectiveness of public universities in Nigeria. Therefore, for a university in Nigeria to be viewed as a hub of developing nations that strive to meet the expectation of the society, the identified hindrances must be thoroughly interrogated and resolved.
\end{abstract}

Keywords: Institutional Effectiveness, Higher Education, Public Universities, Nigeria. 


\section{MALAYSIAN ONLINE JOURNAL OF EDUCATIONAL MANAGEMENT (MOJEM)}

\section{INTRODUCTION}

The effectiveness of the higher education system has been a matter of deep-seated theoretical interest (Kayode, Oduwaiye, Etejere, Sheu, \& Kutu, 2018; Vihma, 2007). Effectiveness is one of the ongoing areas of concern in any organisational discussion (Kaffashpoor, 2013) and the situation is not different in university education in the world and specifically, in Nigeria. Effectiveness is defined as the extent to which the university systems are achieving their stated objectives, and the internal and external effectiveness is normally differentiated. It is the extent to which an establishment's core mission is accomplished. The concept of institutional effectiveness as assessing all the functions of a higher education institution, including accountability, quality control, assessment, efficiency, student educational results, and student success, was developed by the Southern Association of Colleges and Schools (SACS) during the early 1980s (Malone, 2003; Nichols, 1989). According to Serban (2007), institutional effectiveness is the competency of the university system to match its performance to established purposes, as stated in its mission.

The goals of university education in Nigeria as contained in Section B, sub-section 59 of the National Policy on Education (Federal Republic of Nigeria, 2004), include the contribution to the development of the nation using appropriate workforce training; improving and instilling correct standards towards individual and community continued existence. Other goals include: enlarging the conception of the learners to know and be pleased about their native and external surroundings; obtaining both substantial as well as relevant expertise that will make all learners to be self-directed and helpful community members as well as upholding global and domestic understanding (p.26). The policy further highlighted how such aspiration could be attained through teaching, employee advancement programmes, research and service-learning programmes.

University education in Nigeria has been recognised for its role towards the provision of a pertinent workforce for the benefit of both learners and the country at large (Agabi, Obasi, \& Ohia, 2012; FRN, 2004). As such, realising the role of university education as the spark plug for development, Nigeria embraced programmes and policies that predisposed the social demand approach to the supply of knowledge. This lead to the inclusion of university education in the concurrent list in the Nigerian constitution in 1979 (Idumange \& Chukwuemeka, 2009). As laudable as these objectives are, very little progress has been made in actualising them because the potential of university education to produce high-quality graduates in Nigeria is compromised (Olasehinde-Williams, 2012).

Various obstacles to institutional effectiveness have been identified in the literature. Cruz (2011) draws attention to the low commitment of lecturers, inadequacy of the assessment techniques. Also, Cruz (2011) contends that in various institutions, leaders provide insufficient support and that there are poorly planned systems to make use of assessment results. In a study conducted by Agabi et al. (2012), there is substantial evidence that prospective employers of skilled labour consider considered university graduate practical skills, professional ethics, management ability and entrepreneurial skills as mostly inadequate and that these graduates only possess theoretical knowledge. The accreditation Processes of the National Universities Commission (NUC) shows that universities in Nigeria are improving drastically (National Universities Commission, 2012) but paradoxically, the society is simultaneously complaining bitterly that the educational standard of the institutions of higher learning in the country is drastically falling. In a recent survey of universities carried out across the globe, it is of concern that no university in Nigeria was ranked among the top 400 universities in the world. According to Darma (2013), it is even more discouraging to realise that no universities in Nigeria met any of the criteria or indices used in the assessment of the global universities ranking.

Furthermore, despite the massive turn-out of graduates annually, Nigeria is still not able to meet the essential needs and aspirations of the generality of the population. Employers of labour worry that some graduates today are generally unemployable except they are first put through a crash remedial programme (Okojie, 2013) while universities abroad have been hesitant to recognize many Nigerian university certificates without subjecting the graduates of such institutions to other rounds of qualifying examinations (NUC, 2004; Oyebade, Oladipo, \& 


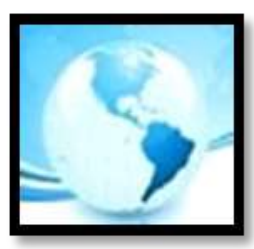

\section{MALAYSIAN ONLINE JOURNAL OF EDUCATIONAL MANAGEMENT (MOJEM)}

Adetoro, 2008). Inadequate practical and technological competencies of our graduates constitute a vast knowledge gap, which has rescinded the supposition of university education as essential and industry established to produce quality workforce towards the development of the nation (Nkang, 2013). The pressures encountered by universities in their drive to be more competitive, efficient and better adapted to the needs of their stakeholders, have all led to a growing and unprecedented level of interest in organisational performance evaluation of institutions of higher learning and in particular, university education in Nigeria (Morrison, 2010).

To find a lasting solution to the decline in the quality of education in Nigerian universities, factors that led to poor quality of graduate need to be addressed. Consequently, this study investigates the issues impeding the effectiveness of public universities in Nigeria.

\section{Research Context}

In response to the recent increase in competition in different sectors of the economy including university education world-wide and most especially in universities in Nigeria, there is the need to deliver high quality graduates, and these have been a significant challenge to the management of the university system in Nigeria. Some of these challenges or issues have been identified by different researchers in different sector of the economy. According to Ekundayo and Ajayi (2009), inadequate funding in the university system has led to scarce resources, continues strike and closure of the school, unconducive staff working environment and poor curriculum implementation and innovation, which affect university effectiveness. As pointed out by lordache-Platis (2019), one of the issues facing higher education in America includes the rising cost of education compared to its benefit in terms of the diminishing field of well-paying job opportunities.

In addition to that, according to studies (Kpee, Oluwuo, \& Baridam, 2012; Okonkwo, Ubani, \& Ubachukwu, 2013), curriculum issues has been a major problem facing higher education in Nigeria. According to Kpee et al. (2012), the curriculum is not developing the student to be a job provider but rather a job seeker and as such, the ability of the government to provide enough white collar job has rendered university graduate unemployed. OlasehindeWilliams stressed this scenario by insisting that the quality of graduate produced in our university system has been compromised due to weak teaching and half-baked education.

Furthermore, moral decadence has been identified as crucial issue that are likely affecting the effectiveness of public universities in Nigeria. According to Asiyai (2013), students nowadays lacks the moral value expected of any university graduate as the goals of university education is to train the recipient of such training, morally and intellectually. However, that is not the case in some instances where some students constitute a threat to both the lecturers and the university management because of the bad behaviour. Ethnicity and corruption cannot be left out as an issue in university administration. For instance, the continuous killings and kidnapping in most parts of the country even at the university campus have made the university environment to become unsafe for learning. Mismanagement of limited resources by the policy makers and university managers has made it impossible to provide the essential facilities needed to bring out effective teaching and learning. That is why even in the university system, the sports pavilion is still being used as a lecture room in some of the university system because of the inadequate lecture rooms.

There is a saying that the effectiveness of any organisation is a reflection of who is leading the organisation (Kayode, Yusoff, Veloo, Oduwaiye, \& Sheu, 2018). According to Mathieu and Babiak (2015), leaders who have no zeal or morals to lead its establishment as a result of the imperfect selection process are likely to affect the effectiveness of the establishment. In the study conducted by Dung (2014), lack of collaboration across the university system as well as lack of financial autonomy as a result of leadership problems is also a significant challenge facing the university system. Other issues identified include bad teachers, discipline issues and lack of student motivation. 


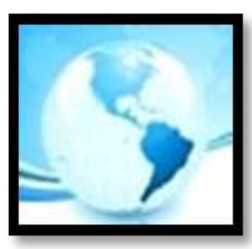

THEORETICAL FOUNDATION

The European Foundation for Quality Management (EFQM) excellence model is a well-linked quality instrument employed by more than 30,000 organisations in Europe to improve its performance (EFQM, 2013). Numerous organisations adopt it as a planning and self-evaluation tool to find out where they are in terms of their performance, their expected return and how to work towards achieving their goals (Arjomandi, Kestell, \& Grimshaw, 2009). The model suggests the use of the RADAR scoring matrix as an instrument for measurement (Arjomandi et al. (2009). The RADAR scoring matrix has five components; The R signifies results in terms of the organisational achievement, A denotes approach in terms of the plans and policies, $D$ connotes deployment in terms of the degree in which the strategies are executed, A signifies assessment in terms of what the organisation does to evaluate and $R$ shows a review of both the approach and implementation of the approach (EFQM, 2012).

Excellence in university education can be reviewed in terms of accomplishing the mission and vision of the institutions, attaining or surpassing the yardsticks and internal measures, best practices, shareholders' satisfaction, community bargaining, and learning outcomes (Hides, Davies, \& Jackson, 2004). Moreover, excellence includes the spreading of good practices nationwide and worldwide, achieving a balance between aspiration and actual assessment, encouraging atmosphere in staff and student surroundings; and maintaining a high quality of teaching and learning (Tabish \& Syed, 2015). Even though the EFQM model was not explicitly created to evaluate university education, there is evidence to support its application in the educational system (Becket \& Brookes, 2008; Claver \& Tarí, 2008; Tarí, 2008). The model has been adopted as an instrument required by leaders to survive the complex transformation, and it concentrates on areas of strength and not marks; areas of progress and not faults (Arjomandi et al., 2009; Davies, Hides, \& Casey, 2001; Tarí \& Madeleine, 2012). The EFQM excellence model has nine criteria, and they are in two segments: the enabler and the results, as depicted in Figure 1 . The enabler comprises of what the university does about leadership, strategy and policy; employee management; partnerships and resources as well as the process management. The results aspect contains four components, namely, people's results, customer results, society results as well as key performance results.

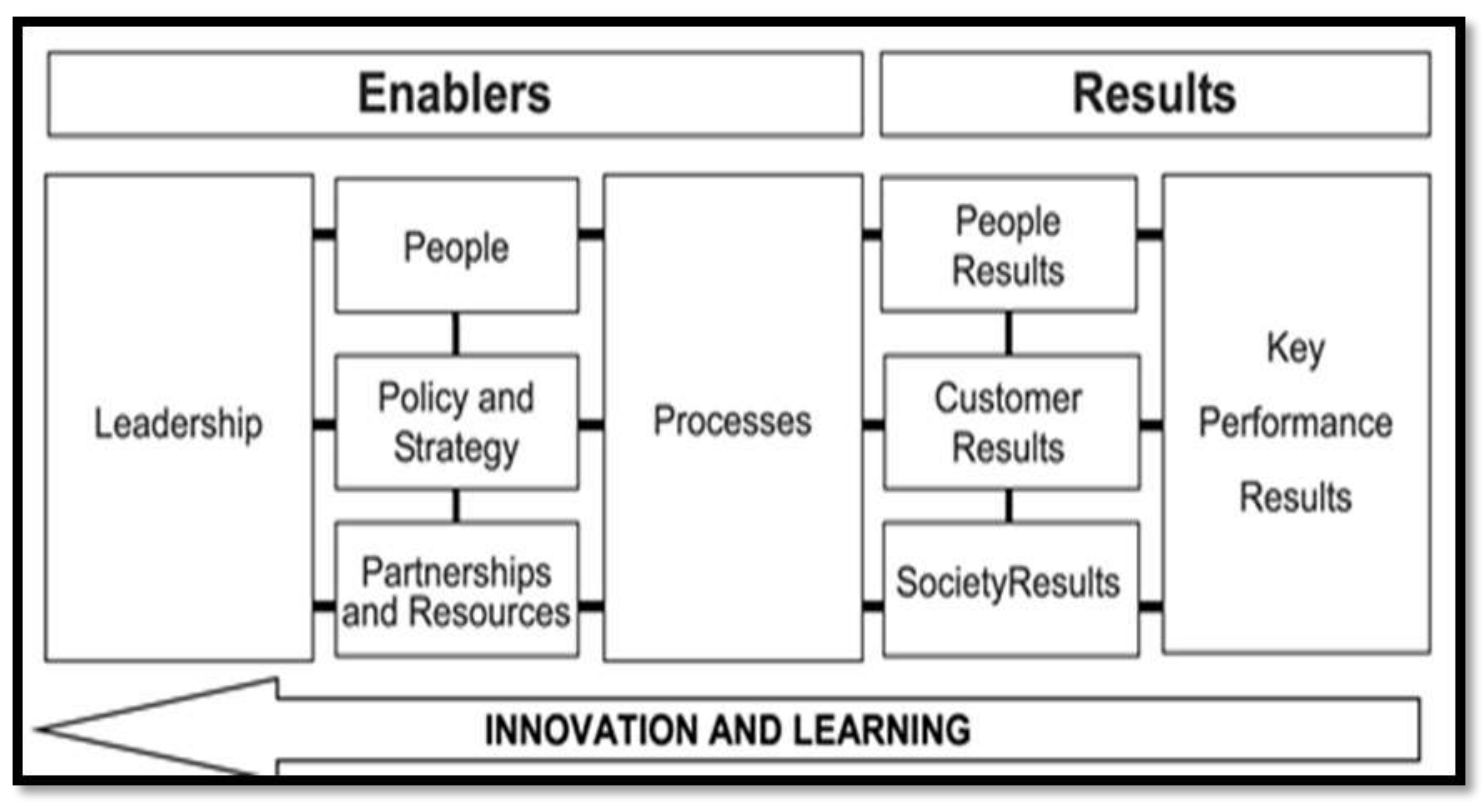

Figure 1. EFQM excellence model (Source: European Foundation for Quality Management, 2013) 


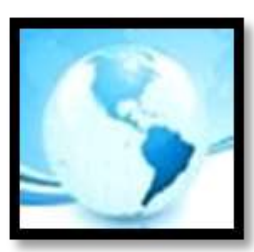

\section{MALAYSIAN ONLINE JOURNAL OF EDUCATIONAL MANAGEMENT (MOJEM)}

For this study, the result section of the excellence model was adapted to examine institutional effectiveness. The EFQM model is perceived to involve contingency theory and total quality management theory and explains input and process (administrative and academic) as the determinant of the performance of an organisation. According to the model, the leader alone may not be able to achieve the predetermined goals of the organisation, and therefore, he/she must involve everyone in the organisation towards the attainment of the organisational goals through policy and strategy, motivation, resource provision, collaboration as well as subordinate satisfaction (EFQM, 2013).

\section{METHOD}

\section{Research Design}

This study is a qualitative report. It adopted a generic qualitative design. The design is suitable as the motivation of this study is to understand the issues hindering the effectiveness of public universities in Nigeria. According to Caelli, Ray, and Mill (2003), the generic qualitative design is not guided by an established or specific set of philosophical assumptions. According to Kahlke (2014), the essence of a generic qualitative method is to find answers to particular questions or study an issue and as such, generic qualitative technique does not match recognised methodologies as it does not focused on building theory, culture (ethnography) or confined on a case study. The generic qualitative inquiry method is suitable when a researcher is examining the top manager about their experiences on a phenomenon (Percy, Kostere, \& Kostere, 2015). Pre-knowledge or understanding about leadership, quality administrative, and academic process as a determinant of institutional effectiveness was initially acquired, which was reflected in the quantitative part of this study (Kayode, 2016). One further questions were asked to broaden the prior knowledge and intrinsically, using generic qualitative inquiry approach is deemed suitable for this study (Percy et al., 2015).

\section{Population and Sampling}

To gain insightful feedback from the participants for the semi-structured interview that was conducted for this study, a purposive sampling technique was adopted. Using the purposive random sampling technique, one deputy vice-chancellor, two deans/provost of a faculty/college, three head of departments, one lecturer and a registrar were selected for an interview in this study. Therefore, a total of eight participants participated in interviews. From the sample, four participants were from state universities and another four from federal universities owned by the central government, making a total of eight participants. The decision for choosing eight participants was built on the suggestions by Onwuegbuzie and Collins (2007), who stated that the sample size for a qualitative study should be moderate. That is, the sample size should not be too small to the extent that data or theoretical saturation or informational redundancy would be challenging to achieve and not be too bulky that a thoughtful case-oriented will be hindered (Onwuegbuzie \& Collins, 2007). This is in congruence with Krueger (2007) who recommends between six to nine respondents in generic qualitative research. The participants were selected because of their rank and their working experience in the university system. These participants have spent at least 12 years in higher education, either teaching or gaining administrative experience or their position ranges from senior lecturer to vice chancellor. As such; it is assumed that they have a better idea of the problems confronting the university system (Chua, 2004).

\section{The Approach}

Semi-structured interviews were employed to unveil and describe the participants' point of view on issues impeding the effectiveness of public universities through a subjective perspective (Marshall \& Gretchen, 2014). Percy et al. (2015) opine that data collection for a generic qualitative inquiry is always in the form of semi or fully structured interview. An individual face-to-face interview (Cohen, Manion, \& Morrison, 2011) of 30 minutes was adopted utilising an interview protocol adapted from Cameron (1978) to gather information from the participants. 


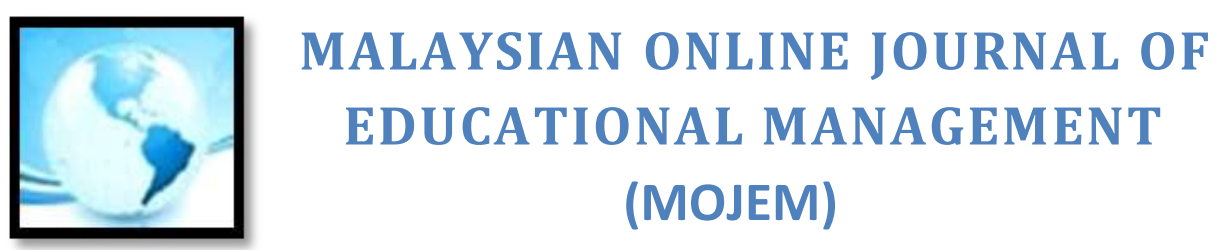

Informed consent was sought from participants and rapport was established before interviews by meeting them. Permission to record their conversations was further secured before the interview. Questions were asked from the participant in such a manner that there was no variation of the content as well as the context of the questions.

\section{Validity and Reliability}

To check for the accuracy of the findings, trustworthiness in terms of credibility, dependability, transferability, and confirmability techniques were adopted (Creswell, 2012). Trustworthy is used to determine the validity and reliability of qualitative research (Suter, 2012). The researchers ask most of the participants in the study to check the accuracy of the transcribed document for verification to establish the credibility of the results as the researchers may have done everything possible to fulfil their role as the main instrument, but bias influence could still occur in the data (Creswell, 2012). Therefore, all participants were given the draft copy of the transcribed data showing the themes generated as a means of feedback and to confirm if what the researcher has done is in line with their views (Kayode, 2016).

Furthermore, the researcher involved the researcher's supervisor who is an expert in a qualitative study with a singular focus on the process of data analysis to attain a clear view of the analysis process as well as the formation of themes for the study. Also, colleagues using a qualitative approach were also consulted to seek their opinion in reviewing the tentative themes established by the researcher to ensure its acceptability. This strategy involves questions and answers between the researcher and his colleagues relating to the study where the themes where modified severally to be aligned with the focus of the research.

\section{Data Collection Procedure}

This study used a semi-structured interview to disclose and describe the participants' viewpoints on issues impeding effectiveness of public universities in Nigeria. In order to gather data for the analysis, a deputy vice chancellor, two deans/provost, three head of departments and two lecturers was interviewed in five of the sampled universities and therefore, a total of 8 interviewees were involved in this study. A semi-structured interview was chosen as suggested by Percy et al. (2015) that data collection for a generic qualitative inquiry are always in the form of semi or fully structured interview. An individual face to face interview (Cohen et al., 2011) was conducted to investigate the issues impeding institutional effectiveness.

An interview protocol was developed to gather information from the participants. A copy of consent letter was given to each participant to seek their consent to participate in the study before the initial interview. The researcher also went back to see them after their agreement to partake in the interview in order to establish rapport with them and a duration of 15-20 minutes was spent with them.

The interviewee supplied necessary information about what the research entails most especially the introductory segment and their cooperation was requested in terms of their time and valuable information that will enhance the achievement of the research. Questions were asked from the participant in such a manner that there was no variation of the content as well as the context of the questions. The researcher seeks the permission of the interviewee to record their conversation and an audio tape was used for the recording. However, such device was appropriately tested and used in order to be sure of the effectiveness and how reliable is the device. The interview protocol was adapted from Cameron (1978) and at the end of every interview, the respondents were appreciated for taking their time.

\section{Data Analysis}

Interview data were analysed using thematic analysis (Percy et al., 2015), which is a process of pinpointing, analysing, and reporting patterns within data. The themes were patterned across data sets that are important to 


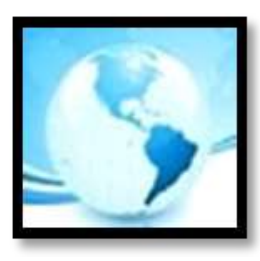

\section{MALAYSIAN ONLINE JOURNAL OF EDUCATIONAL MANAGEMENT (MOJEM)}

the description of the phenomenon (Daly, Kellehear, \& Gliksman, 1997). The transcripts of the audio tapes that were recorded during the interview were analysed using a computer software packages for qualitative data analysis called Nvivo 10 produced by QSR international.

\section{RESULTS}

The researchers organised the results of this qualitative study into themes and sub-themes based on the information gathered from the participants. In the analysis, five themes and 17 sub-themes emerged on the issues impeding the effectiveness of public universities in Nigeria. The sub-themes were collapsed into themes using theoretical and inductive analysis techniques of thematic analysis, respectively (Percy et al., 2015).

To identify the issues impeding the effectiveness of public universities in Nigeria, the researcher employed two phases during the data analysis. The first phase was preparing the data and working on assigning the data units to predetermined themes derived from the quantitative study. In the second stage, the researcher work with the data units and patterns that did not seem to fit the predetermined themes (Percy et al., 2015). In other words, the data unit that fit into the themes: leadership issues, academic issues and administrative issues were identified, and in the second stage, two themes emerged as other issues affecting institutional effectiveness. These two issues are funding and contextual factors.

\section{Demographic Profile of the Participants}

This qualitative aspect of the study gathered information from 8 participants with a semi-structured interview. The participants were purposively selected to provide the relevant information needed for this study (Table 1).

Table 1

Demographic profile of the participants

\begin{tabular}{llll}
\hline S/No. & Pseudonyms names & Rank & Experience \\
\hline 1. & Participant 1 & Professor and deputy vice-chancellor & 28 years \\
2. & Participant 2 & Professor and Dean of a faculty & 30 years \\
3. & Participant 3 & Professor and Former HOD & 20 years \\
4. & Participant 4 & Professor and HOD & 17 years \\
5. & Participant 5 & Professor and HOD & 23 years \\
6. & Participant 6 & Senior Lecturer and Ag. HOD & 10 years \\
7. & Participant 7 & Lecturer I & 10 years \\
8. & Participant 8 & Professor and Director of a Unit & 15 years \\
\hline
\end{tabular}

\section{Issues Impeding Universities Effectiveness}

This section provides an in-depth understanding of the issues impeding the effectiveness of public universities in Nigeria. Based on the thematic analysis using theoretical analysis types of approach, many issues as shown in Figure 2 were identified and were then categorized under five themes namely, academic issues, administrative issues, leadership issues, funding issues, and contextual issues. 

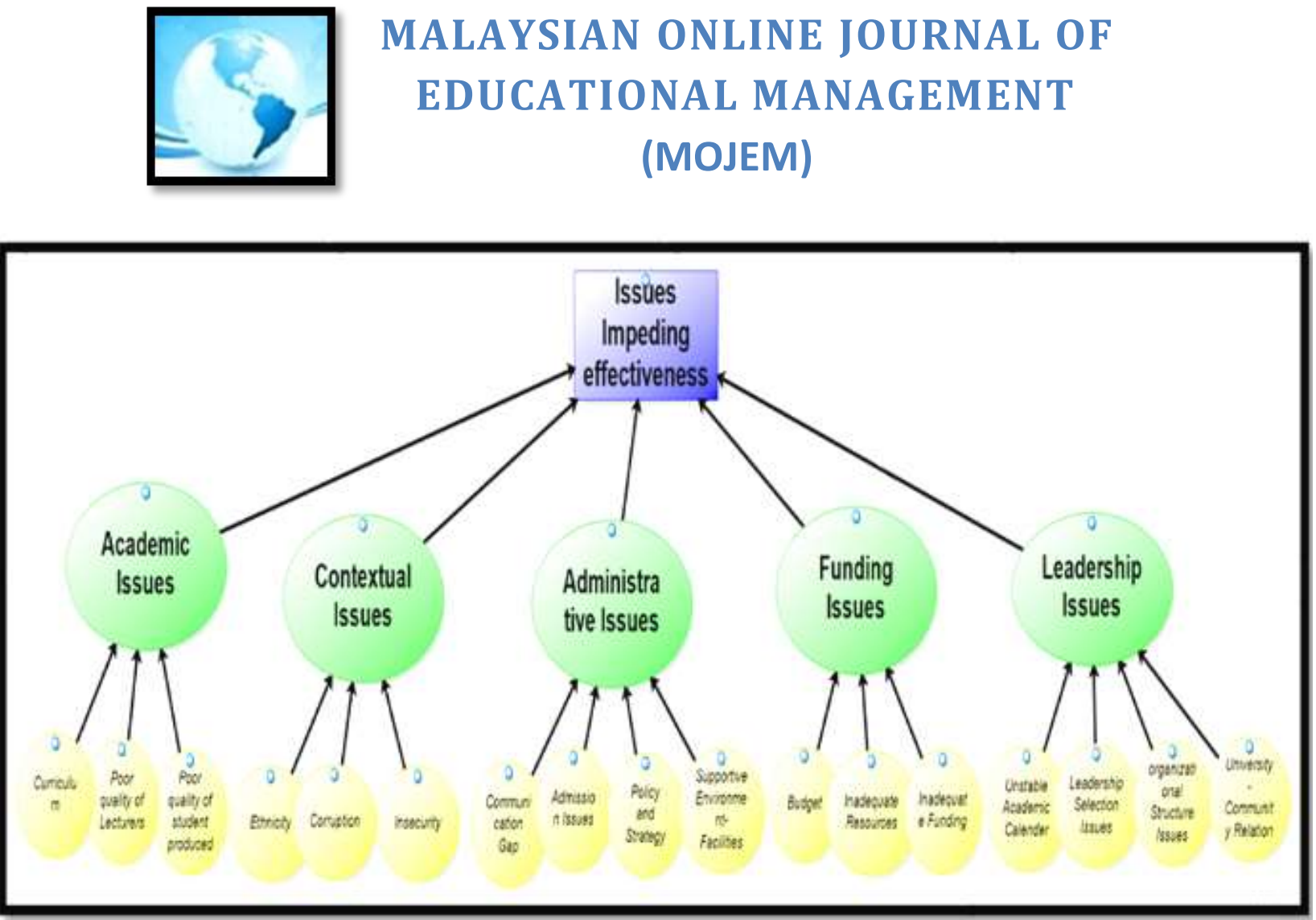

Figure 2. Issues impeding universities effectiveness

\section{Academic Issues}

Academic issues in this studies relate to the educational and research process as identified by Calvo-Mora, Leal, and Roldán (2006), which include curriculum, instruction, assessment, service learning, and research. However, the responses from the participants indicated that curriculum, poor quality of student-produced at the foundational level, and the quality of lecturers are the primary academic issues impeding institutional effectiveness. These were illustrated in Figure 3. 


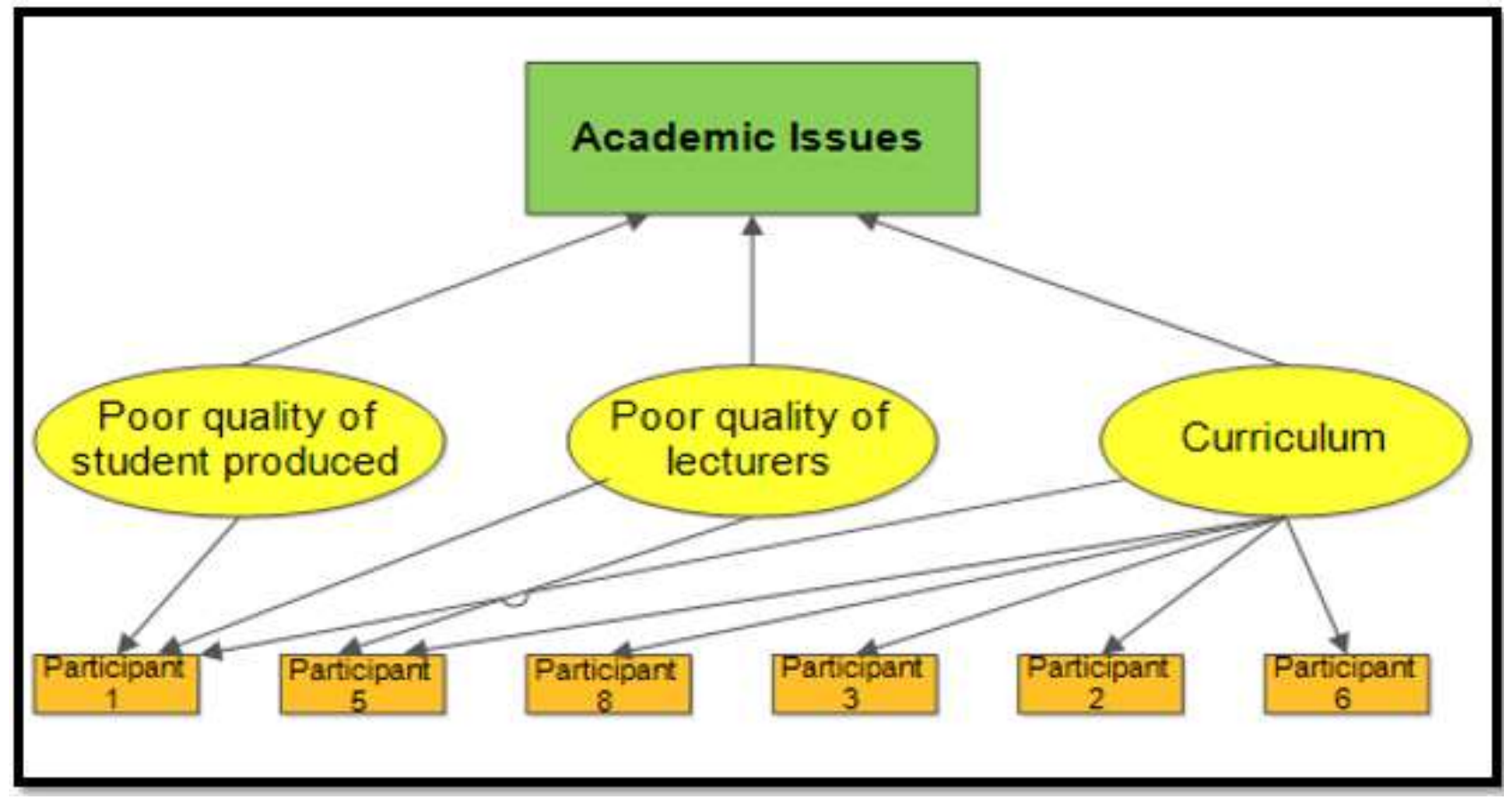

Figure 3. Academic issues as a factor impeding universities effectiveness

As highlighted by Participant 2: "The Universities are not aligning their curriculum to the needs of the industries for which they are producing students in the various faculties."

The informant went further:

"One of the significant issues also lies in curriculum development and implementations. The Nigerian universities curriculum does not regularly review to meet up with the global trends, and if Nigerian universities want to be competitive with other universities in the world, there is a need for a drastic review of the curriculum. The curriculums are not tailored to reducing the trend of increased unemployment in the country because we are training our graduate for white collar job but not to be self-employed. Even with the introduction of entrepreneurship education all higher education in Nigeria, much has not been achieved because they are not in line with the student course of study "(Participant 8, 26082015).

As stated in the National Policy on Education (2004) that no nation can rise above the quality of its teachers, the quality of lecturers determines the quality of education. As observed by Participant 1, "There is evidence from states that the quality of teachers is not anything to write home about." This was also consistent with the observation of Participant 5, who said:

"We have the challenge of the facilitators (the lecturers) we have a lot of lecturers that are not well exposed to training, not be able to meet with scholars around the world not able to travel out of their local environment "(Participant 5, 09072015).

The poor quality of student-produced at the foundational level has also been identified as one of the issues impeding the effectiveness of university education in Nigeria. As observed by Participant 1 :

"Stressing the quality of students, there is no way we are going to isolate the quality of students at the tertiary level from the quality of students at the foundation level. The primary level, the 


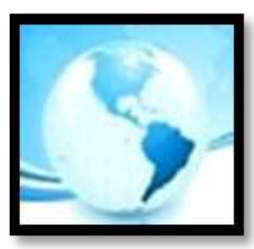

\section{MALAYSIAN ONLINE JOURNAL OF EDUCATIONAL MANAGEMENT (MOJEM)}

secondary school level (which is the intermediary between the tertiary and the primary) have their share of the blame. What the University can do depends largely on the quality of students that they admit. If the foundation is weak as it is, and everybody has admitted that! Then how much can the University do to be able to ameliorate these deficiencies from the lower levels" (Participant 1, 24062015).

The ability of the student to cope academically with university education is a result of the student's foundational knowledge at primary and secondary school. That is why some students are rusticated from the system when they were unable to attain the required CGPA to move to another level in their study.

\section{Contextual Issues}

Contextual factors in terms of ethnicity, corruption, and insecurity were also one of the identified factors affecting universities effectiveness.

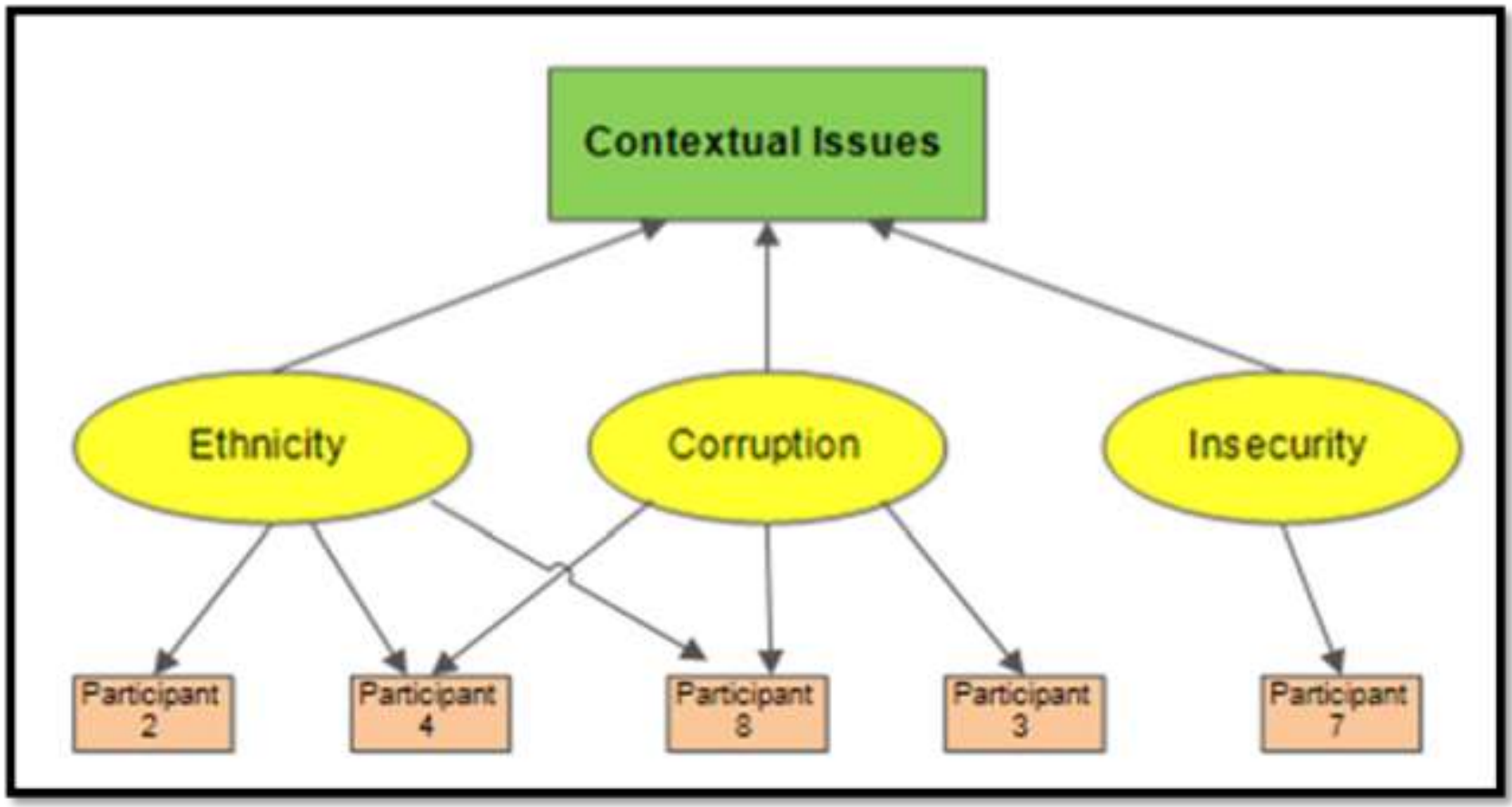

Figure 4. Contextual issues as an impediment to universities effectiveness

Giving ethnicity priority over merit in admission and recruitment processes because a candidate is from a particular region has been identified as a factor inhibiting institutional effectiveness which Participant 2 called social, environmental influences especially in university leadership selection.

The above statement was supported by Participant 8 who stated that:

"The politicisation of appointment and promotion in the university system is a significant issue that needs to look into as this does not encourage merit and hardworking among staffs which hurts the system and the society at large" (Participant 8, 21072015).

Corruption has been identified as one of the major setbacks to the effectiveness of public universities in Nigeria. According to Participant 3, who stressed that: 
"...there is corruption in Nigeria, corruption among the leaders. I was discussing with my colleagues the rate of corruptions at all levels in the university. Vice-chancellors are corrupt; deans are corrupt, HODs are corrupt, even lecturers ordinarily are even corrupt students" (Participant 3, 07072015).

This argument on corruption as it affects the university system was also stressed by Participant 4, who said:

"The culture of corruptions among university management is not helping matters as the little available budgets for facilities, and staff welfares are being diverted for personal use. Also, student bribe their way in order to pass their exams and so many atrocities committed by other university staff, this has affected seriousness on the part of students when they know that they can pass their course without much effort and because of the large number of applicants some staff demand bribe for admission" (Participant 4).

Insecurity was also identified as a contextual issue in university education, affecting its effectiveness. According to Participant 7:

"The general insecurity we have in Nigeria, which from my observation has contributed to skilled distribution of students seeking admission across the country. Before now, perhaps maybe in the 60s and 70s, students travel, student gain admission across the country. From the east from to the north, from the south to the west, they cut across-university to get an admission that to some extent ensure some level of even distribution of students in a way that 1 or 2 or 3 universities are not over pressurised in terms of those seeking admission. That is, because of insecurity people are not confident in leaving their wards to places, so everybody tends to look for universities within its locality" (Participant 7,16072015).

\section{Administrative Issues}

Another issue identified by the respondents is termed in this study as administrative problems. Factors identified by the respondents include communication gap among stakeholders, admission issues, deficiency in supportive environment/facilities as well as poor policy and strategy implementations. The graphic representation is shown in Figure 5. 

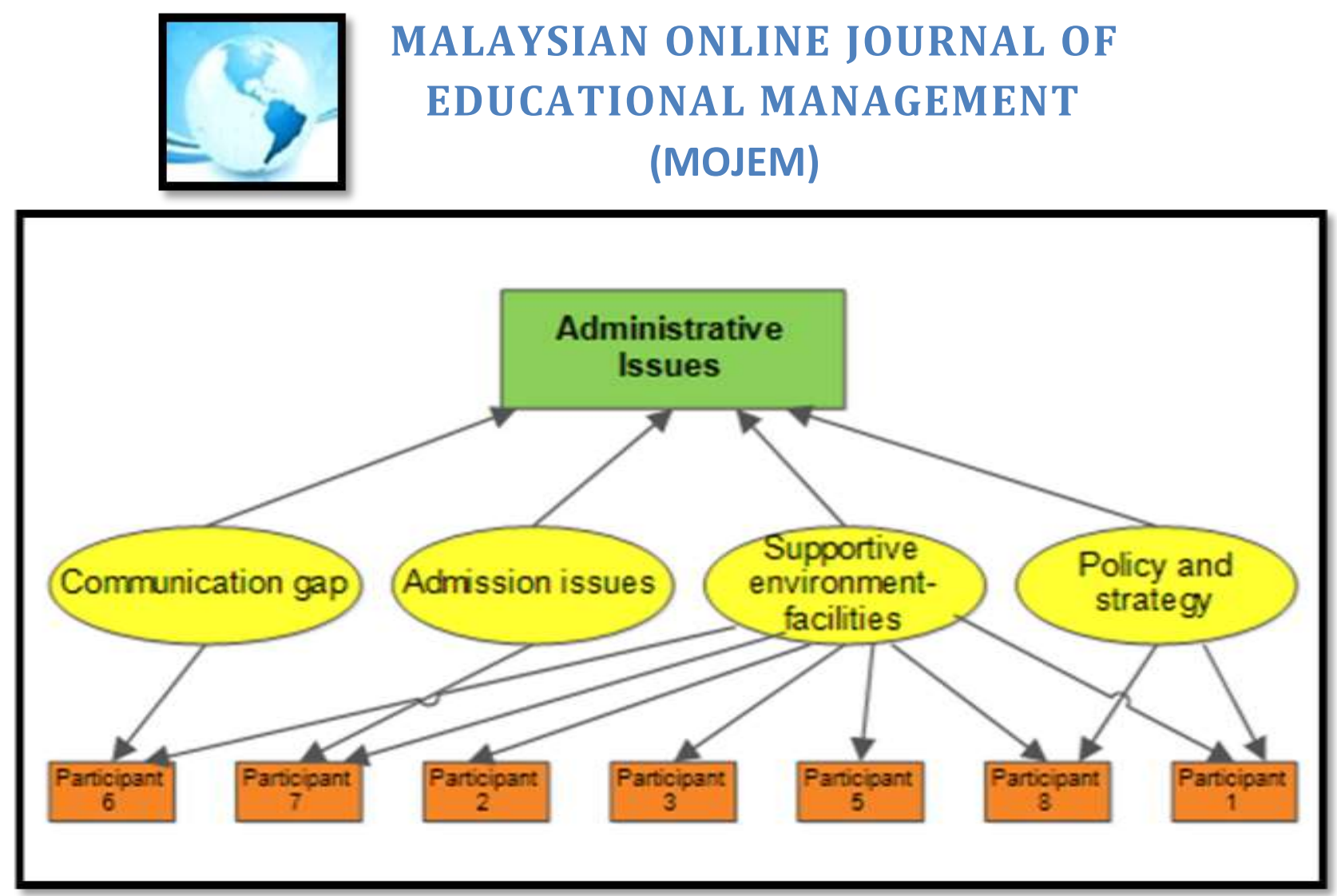

Figure 5. Administrative issues as a factor impeding universities effectiveness

Communication gap which is a failure of understanding, usually because of a lack of information, especially between different stakeholders in the educational system. As observed by Participant 6, "the extent that other stakeholders are carried along is very minimal." This can affect the implementation of educational policies when those who are to implement those policies are not adequately informed or carried along in the process of policies making which can bring about poor participation on the part of the subordinates or implementers.

Also, Participant 7 stressed that "there is no correspondent between the available institutions and numbers of a candidate seeking entrance into those institutions." The Post-UTME is conducted to reduce the number of qualified students because of the large number of applicants.

Therefore, the issues of selecting the best candidate have been compromised because of the large number of applicants compared to the available quota. For instance, over 110,000 students choose a particular university as their choice during the Unified Tertiary Matriculation Examination (UTME), and the said university has less than 11,000 quotas.

According to Participant 1:

"..Right from the primary or foundation level down to the tertiary level, there is clear evidence of decay in infrastructure in many schools; classes are being merged at the primary school level to accommodate inflows of children after widely access through Universal Basic Education which is not suitable for teaching" (Participant 1, 24062015).

This issue of inadequate facilities was further buttressed by Participant 5 who said, "there are challenges in the university system, from admission we have challenges because a lot of qualified candidates are not admitted in the university system because we have limited facilities in the university system." He further stressed that "we need an environment that is conducive to practice our work and we can imagine now that in the university where we 


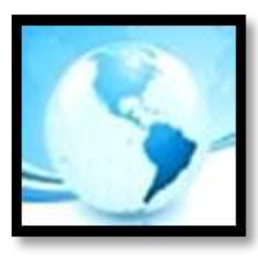

\section{MALAYSIAN ONLINE JOURNAL OF EDUCATIONAL MANAGEMENT (MOJEM)}

struggle to get electricity, all these things are not like that in another part of the world." This was also in line with Participant 7, who said:

"When electricity is not available, it frustrates curriculum content delivery because you schedule a lecture and you are unable to deliver well simply because the supporting facilities are available, so what do you do? You get frustrated, and you end up not reading what is supposed to be given to the students" (Participant 7, 16072015).

The importance of facilities for student learning was further bolstered. According to Participant 7:

"From my experience to be able to deliver on the second leg of the curriculum content delivery, there is a need to be a balance between human capability and material availability. No matter how good the lecturer or teacher and even the Lab attendant or technician are, if the equipment is not available to help guide the students to acquire necessary skills of practice, there is little they can do" (Participant 7, 16072015).

There is equally "lack of motivation among staffs or they felt somehow cheated or somehow neglected by the system" (Participant 6, 13072015). This was supported by Participant 7 stated that:

"The academic staff is complaining that they are entitled to specific allowances as a result of an increase in population not necessarily because the facilities coming to them are not enough, they are saying since there is an increase in population, there should be commensurate allowances in workload" (Participant 7, 16072015).

Moreover, one of the identified issues relating to supportive environment/facilities is staff training and development which, according to Participant 8:

"Our universities' leaders are not helping matters in staff training. Staff is not provided with the necessary support or training to improve their efficiency and effectiveness. The money that is to be used for staff training is side-tracked for other purposes. The conditions under which the lecturers are carrying out their roles are not conducive, and as such, much cannot be realised in them being productive. For example, no favourable office, poor or no access to internet facilities, inadequate furniture, poor welfare packages, and irregular promotion exercise and these factors have demotivated the academic staffs in putting up their best in teaching and research" (Participant 8, 21072015).

Although, Participant 7 also observed that even the limited facilities that were provided "there has been the corresponding observation that these resources are not being managed very well." Seven out of the eight participants in this study identifies poor supportive environment and facilities as a factor impeding the effectiveness of public universities in Nigeria.

The result of the interview conducted for this study further identify policy implementation as one of the factors impeding the effectiveness of public universities in Nigeria. One of such issues lies on disjointed efforts between the policy maker and the implementers of such policy. According to Participant 1, "if policies are made at the federal level and are not getting to the training institutions, that is a gap to be corrected." Participant 1 went further:

"Gaps between the training institutions, the world of work, the superintending bodies like NUC itself, like the Federal Ministry of Education, the Universal Basic Education Commission. I think there is a big gap to be filled between these bodies and the University in a way that the University will be able 


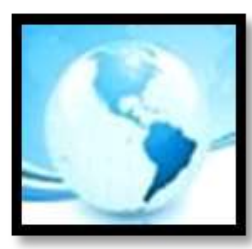

\section{MALAYSIAN ONLINE JOURNAL OF EDUCATIONAL MANAGEMENT (MOJEM)}

to respond to new policies, for example, I understand that a new Policy on Education has been published, it has not reached the faculty of education" (Participant 1, 24062015).

\section{Leadership Issues}

The leadership issues both at the institutional and unit level identified in this study include leadership selection, organisational structure, unstable academic calendar, and university-community relation (See Figure 6).

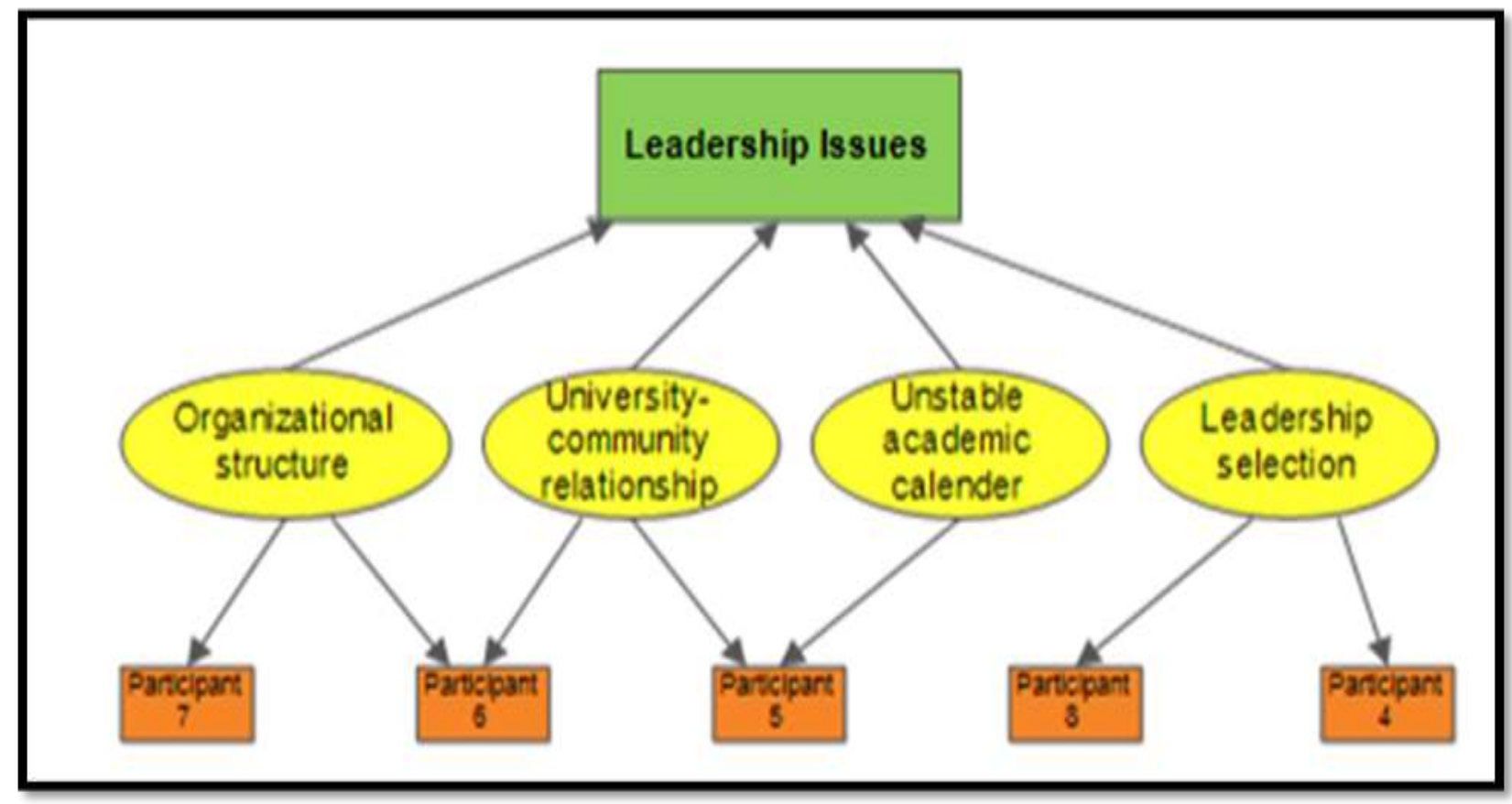

Figure 6. Leadership issues as a factor impeding universities effectiveness

As conflict is inevitable, the structure put in place by the leader determines how conflict can be prevented or managed in an organisation, as stated by Participant 6: "the universities system in Nigeria lack proper organisation sometimes you begin to wonder whether each unit is working at different goals... and as such you don't see a kind of coordinated effort among them".

According to Participant 3, "our mentality that a unit is trying to claim that he is more important than the other unit." This was supported by Participant 7, who said: "it has been discovered that unnecessary bigmanism are in place among various units" because "there is a low level of coordination between different units." This, according to them, has obstructed the university system in achieving their stated objectives.

As identified by Participant 5:

"crisis in the academic calendar which has made a university system like a mockery of what the university system is to be, where the university system will go on strike and the educational activities will suffer for months and a times year "(Participant 5, 09072015).

Participant 5 explained further that "when we have struck all over the places, we are certainly going to have kind of deteriorating quality of education." Therefore, public universities cannot be active if there is a continuous closure of the school. 


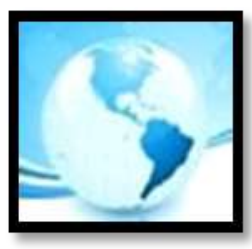

\section{MALAYSIAN ONLINE JOURNAL OF EDUCATIONAL MANAGEMENT (MOJEM)}

Malpractices in leadership selection have been identified as one of the factors inhibiting the effectiveness of public universities in Nigeria. According to Participant 4:

"Some of them because you may see someone that is very effective to become a vice-chancellor but because he is not a native of this town so they will pick someone who may not be as effective as that person" (Participant 4, 09072015).

This was further buttressed by Participant 8 who said: "Other problems include picking the wrong candidates to head the universities because of his connection or to favour his ethnic group which may not be the best for the educational system." Therefore, the inability of putting the right candidate to head the university system is a threat to university effectiveness.

\section{Funding Issues}

Funding is seen as the life wire of any establishment as no organisation can succeed without funding, be it business or public-oriented. Funding has been identified by six out of the eight respondents in this study as the major challenge affecting universities effectiveness. Issues relating to funding as defined by the participants include low budget, inadequate funding, and inadequate resources (See Figure 7).

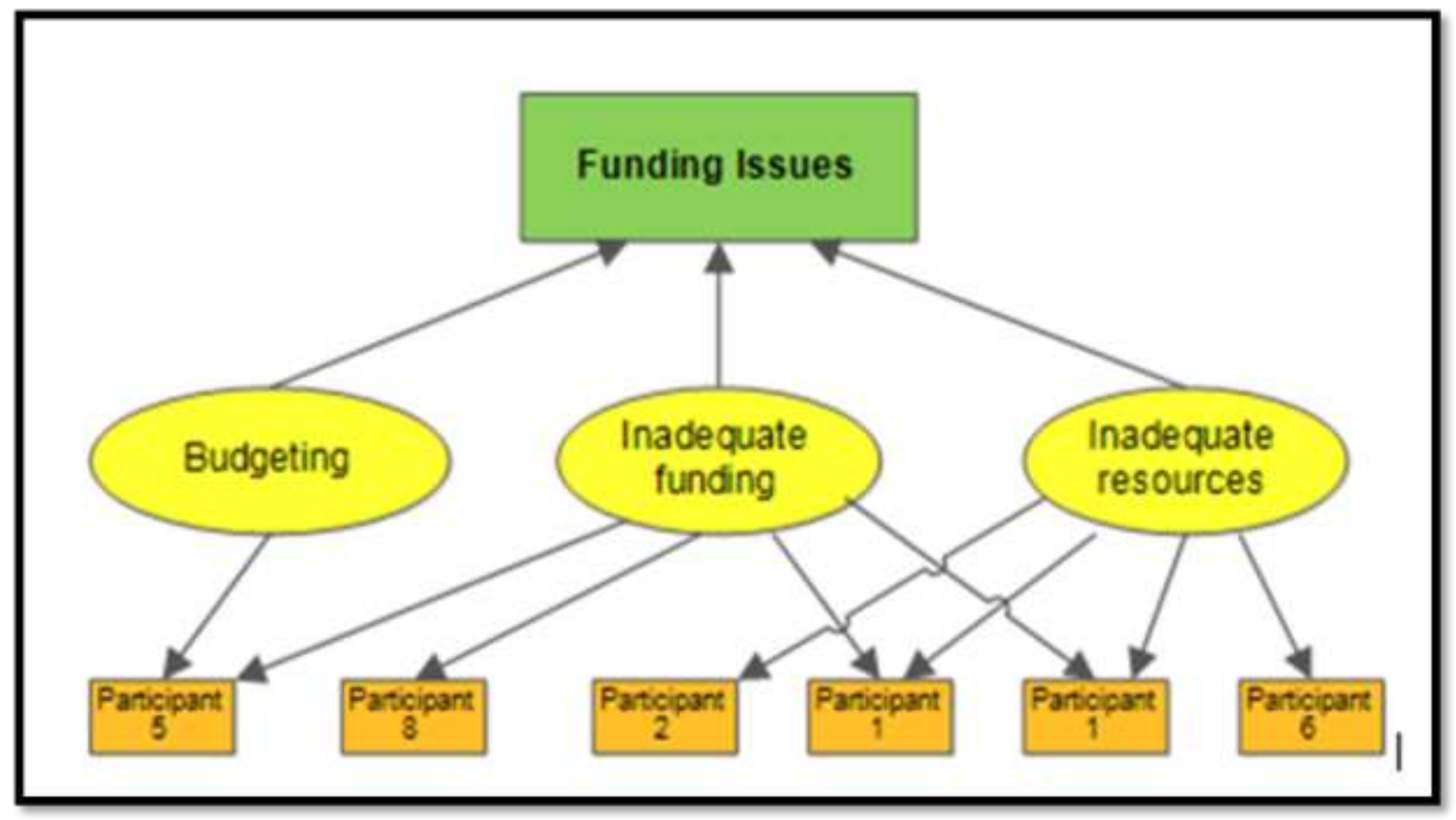

Figure 7. Funding as an impediment to universities effectiveness

Insufficient or low budget is the inability of the government to allocate a higher percentage of either the state or the country's budget to education. As recommended by UNESCO, $26 \%$ of a country's budget should be allotted to the education sector. The low budget has, by the participants in this study as one of the issues impeding the effectiveness of public universities in Nigeria. According to Participant 5:

"Well, one of the significant challenges that are facing the university system presently in Nigeria is 


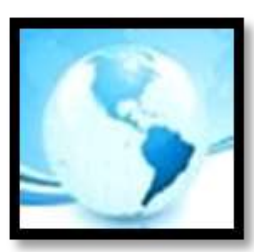

allocation of government funding which more often than not is inadequate, and in a situation, we have insufficient funding, that means many things will have to suffer "(Participant 5, 09072015).

This was also supported by Participant 3 who said that:

"Because the funding is inadequate, it is affecting many areas, it is affecting even curriculum innovation, and it is affecting curriculum development. Having no money to move around, and if you want to bring innovation to the curriculum, you need to send people around the world "(Participant 3, 07072015).

Furthermore, as stated by Participant 1:

"Right from the primary or foundation level down to the tertiary level, there is clear evidence of decay in infrastructure in many schools; classes are being merged at the primary school level to accommodate inflows of children after widely access through Universal Basic Education which is not suitable for teaching" (Participant 1, 24062015).

\section{DISCUSSION}

The issues impeding the effectiveness of public universities in Nigeria as identified by the respondents are classified under five themes using theoretical analysis approach of thematic analysis. These are academic issues, administrative issues, leadership issues, contextual issues, and funding issues.

\section{Theme One}

Academic issues have been identified as one of the problems impeding the effectiveness of public universities in Nigeria. The result of the interview conducted reveals that curriculum, poor quality of teachers, as well as poor quality of student-produced at a foundational level, are the significant issues identified by the participants which were grouped by the researcher as academic issues. Most of the participants interviewed blamed the university curriculum as a factor contributing to unemployment among universities graduate. To them, the curriculum is not developing the students to be employers of labour but rather a job seeker with little or no practical knowledge. The findings of this study are in line with previous studies (Kpee et al., 2012). The introduction of entrepreneurship education in all higher institutions of learning as a way of reducing graduate unemployment in Nigeria is a welcome development. However, the students in various faculties were not trained in alliance with their course of study, and much has not been achieved as a result of incompetent teachers to groom the students (Olorundare \& Kayode, 2014).

Furthermore, poor quality of students produced at foundational level has also been identified as a significant concern (Francis, 2015), as little or nothing can be done by the university to improve such student's intellectual abilities, the student either drop out of the university system or graduate with lower grade and has nothing to show as university graduate. Ss stated in the National Policy on Education (2004), no nation can rise above the quality of his teachers. The results of the interview identify Poor quality of lecturers as one of the impediments to universities effectiveness. The lecturers are the hub of the university system, and they are the primary determinant of the quality of education in the university system because they diffuse the policy of the university system into actions and practices (Voss, Gruber, \& Szmigin, 2007). Weak teaching force will produce a poor quality of graduate with half-baked education, which, according to Olasehinde-Williams (2012), when the processes are compromised, the end product will be of low quality.

A university system with an inadequate number of lecturers who are well-informed, inspiring and are fully prepared to be accountable in their responsibilities cannot attain good quality of education and as such inhibit a 


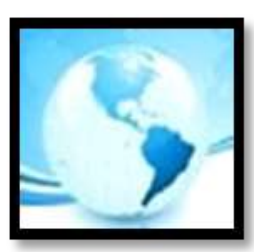

\section{MALAYSIAN ONLINE JOURNAL OF EDUCATIONAL MANAGEMENT (MOJEM)}

challenge to the university system in meeting the challenges of the ever-changing world (Asiyai, 2013; Ekundayo \& Ajayi, 2009). The finding is in line with resource base view which stipulated that the effectiveness of an organisation is predicted by the quality of its human resources like lecturers and as such, quality academic process is positive and significantly related to the effectiveness of the university system.

\section{Theme Two}

Furthermore, the contextual factors are one of the determinants of organisational outcome (Huitt, 2003). The respondents identify the prevalent issue of insecurity, corruption, and ethnicity as a factor inhibiting the effectiveness of public universities in Nigeria. The widespread kidnapping, cultism, and 'Boko Haram' has brought the Nigerian higher education under siege (Onoyase \& Onoyase, 2005). According to Asiyai (2013), some students openly cheat in the examination, and when caught, will threaten to kill the lecturers if he/she make any case regarding his conduct. Many academic staffs have being lost to several killings, and the 'Boko Haram' insurgent has targeted the school system in their operations. For instance, about 420 Chibok students in the north-eastern part of Nigeria was abducted in April 2014 by the so-called insurgents and the whereabouts of those students up till now, are unknown. These negatively affect the university role in producing the future leader of society.

Aside from insecurity, is corruption and ethnicity. According to one of the interviewees, they lamented at the rate of fraud in the university system by stressing that even the vice chancellor to the students, a lot of them are corrupt. This is also evident in the recent ranking of corrupt countries by the transparency international. According to them, Nigerian was ranked $40^{\text {th }}$ among 183 countries in the world, and they stress further that aside from the police, political parties, and the legislature, the educational system is the next in the corrupt ladder. This was equally highlighted by Uche (2014) who said the nuisance of corruption dogging the political system is gradually permeating the university system where all the university administrators and even the students are involved in different corrupt practices. The prevailing sentiment of ethnicity in appointment and promotions has also prone a challenge to the university system because the right person is not allowed to occupy the vacant position. That is why there are mismanagement of resources in the university system (Seo, 2013).

\section{Theme Three}

From the expression of the participants for this study, it was observed that the researcher categorises communication gap, admission issues, low supportive environment/facilities as well as poor policy implementations as administrative issues affecting public universities' effectiveness. As reviewed in the thematic analysis of this study, seven out of the eight participants identified a deficiency in supportive environment /facilities as a significant factor affecting universities effectiveness. This is because no matter how lecturers are determined to be effective if the resources like classrooms, teaching aids, and conducive environment are not made available, there is little such lecturer can do.

Admission of students into the university system in Nigeria especially public universities has posted a significant issue as there is a vast difference between the number of applicants in relations to the number of students a university is to admit using the quota provided by the National Universities Commission. Three significant factors are considered in the selection of student into the public university system. One is the student on Merit (40\% of the quota), Catchment Area (40\%) and Education Less Developed (ELD) state (20\%). However, as stressed by Participant 7, "the university is unable to resist the surge of the candidates, and they take more than what they can cope with." The circumstances can result in sparse learning, where:

"The teachers that are supposed to teach a skills-based course which by expert evaluation should not be burden say maybe 30 students - 1 teacher is now given three times that number certainly the level and quality of teaching and even evaluation and monitoring necessary to ensure that student acquire those skills is undermined" (Participant 7). 


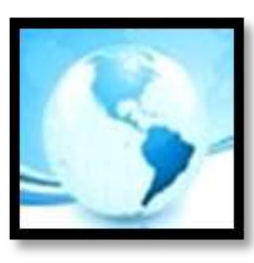

\section{MALAYSIAN ONLINE JOURNAL OF EDUCATIONAL MANAGEMENT (MOJEM)}

As pointed out by one of the respondents, a lot of intended practical classes are converted to a general level because of inadequate facilities. This finding is consistent with the need assessment survey carried out by the NUC; the study reveals that over $60 \%$ of Nigerian students have no adequate access to workshops, classrooms, excellent laboratories, lecturer halls and modern libraries (Okebukola, 2005). According to Adeboyeje (2003), the increase in disruption, crises, and hostility within the university system will bring about a low level of standard and quality of graduate.

Aside from dilapidated building and facilities, the inadequate training and mentoring in the university system is also an issue. University staffs, especially faculty member who are not continuously retrained to exposed them to discoveries and modern methods, will later become irrelevant to the organisation (Adeogun, 2006). These training and retraining are crucial in this technological era, especially with the use of modern technologies for teaching and research.

The term Policy is a blueprint of the universities activities which are repetitive/ routine. Strategy, on the other hand, is concerned with those organisational decisions which have not been dealt/ faced before in the same form. The strategy might be viewed as the value-based (longer term) approach to how a vision (policy goal) can be realised in broad terms, e.g., specification and setting up of action directions and various programs. In every organisational activities and actions, it is the policy that provides an official backing to be followed without any bias by every individuals, groups, department or faculties as applicable to the university system (Adetunji, 2015). Poor policy implementation in the area of the internship was identified. The internship which is termed different names in different field of studies. For instance, student industrial and work experience scheme (SIWES) in sciences, teaching practice in education, houseman ship in health sciences are policy been put in place as quality assurance measures for student to get themselves acquainted with the outside world of work but unfortunately, the exercise according to one of the respondents have been compromised. As stressed by Participant 8:

"The practicum that will send our students out to industries or organisation for practical experiences is not monitored to bring out the best in students. That is another way to make the student have practice knowledge, I mean knowledge application in their area of study but both the university system, the lecturers, the students themselves and even the personnel in the organisation whose the student is attached with are not taking the exercise seriously" (Participant 8).

\section{Theme Four}

Also, poor leadership has been identified in this study as a significant factor affecting the effectiveness of public university education in Nigeria.

Maintain a good relationship with the community where an institution is located is one of the priorities of the university administrators. The university needs to get the community involved in some of the things going on in the school and the community; on the other hand, need to contribute their support to the effectiveness of the school. However, according to Participant 5:

"We also have the problem of even the town and gown relationship whereby the town doesn't even know what the gown is doing, and the gown does not relate with the town, and in such situation, there is a problem" (Participant 5, 09072015).

The statement was supported by Participant 6 when he said, "the extent that other stakeholders are carried along is very minimal." These, according to them, have obstructed the effectiveness of university education in Nigeria. 


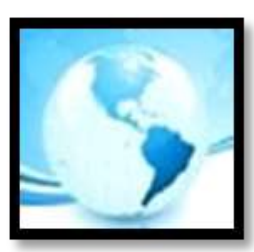

\section{MALAYSIAN ONLINE JOURNAL OF EDUCATIONAL MANAGEMENT (MOJEM)}

The result of the semi-structured interview conducted revealed that poor leadership in the university which bring about the unstable academic calendar as a result of frequent labour dispute and closure of the school; poor organisational structure; poor university-community relationship and leadership selection malpractices. This findings of this study are consistent with Asiyai (2006) who identified the frequent closure of the school to the inadequate funding and poor condition of service for university staff and dispiritedness attitude of some of the university leaders. Furthermore, the inability of some universities' leader to maintain a good relationship with its immediate environment prevent the community from contributing their quota to the effectiveness of the universities. As stressed by one of the interviewees, the community is not aware of the happenings in the university, and the university is not with the community.

A university where a candidate is being appointed to head a school without proper selection processes will bring about selecting the wrong candidate who has no zeal and morality to lead such university and as such; inhibit the university in achieving its pre-determined goals (Mathieu \& Babiak, 2015). The poor organisational structure can also emerge in such university where the leader is not competent enough. In a study exploring the challenges of middle leadership in Vietnamese university, Dung (2014) using interpretive research paradigm interview ten midlevel leaders about their leadership experience and perceptions of the challenges facing Vietnamese university. The outcome of the study using thematic analysis as data coding framework revealed that lack of collaboration across the university's unit and lack of autonomy- in terms of financial and staffing decisions are the major challenges facing the university.

\section{Theme Five}

Lastly, funding is identified as the drivers of sustainability in any organisation. The findings of this study revealed low government budget, inadequate funding, and resources as a major challenge impeding the effectiveness of university education in Nigeria. The government, in their effort, are trying but have not met up with the allocation of $26 \%$ of the federal budget to the educational sector (Ekundayo \& Ajayi, 2009). The financial constraints in the university system will bring about severe working conditions for both academic and non-academic staffs in the school and as a result, inhibit the university system in accomplishing academic excellence (Nir \& Zilberstein-Levy, 2006).

\section{IMPLICATIONS}

In the university settings, four major prevailing actors are the practitioners, the policy makers in government, the university system itself and the employees. Thus, the practical implication will be directed to these players. Therefore, several suggestions for practice were discussed:

It is a well-known fact as stressed by the respondents that one of the issues impeding the effectiveness of public universities in Nigeria has to do with poor quality of students produced at the foundational level most notably at the lower basic schools. The poor quality of students is a reflection of the attitude of the governments both at the local and state level towards basic education. As such, if urgent attention is not given to basic education in terms of prompt payment of salary and other emoluments to boost the morale of teachers in such schools as well as provision of necessary facilities to enhance productive teaching and learning, the product of such schools will continue to be a burden to higher institutions in the country.

The reduced funding has brought about inadequate resources in the university system, which inversely affect the effectiveness of the university system in producing the needed workforce for the country. According to Ekundayo and Ajayi (2009), inadequate funding in the university system has scarce lead resources, continues strike and closure of the school, unconducive staff working environment and poor curriculum implementation and innovation, which affect university effectiveness. Therefore, the role of funding in the effective operation of the university system cannot be undermined. 


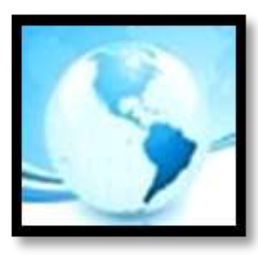

\section{MALAYSIAN ONLINE JOURNAL OF EDUCATIONAL MANAGEMENT (MOJEM)}

The Policymakers who intend to improve university's effectiveness may need to thoroughly examine both the administrative processes as well as the leadership practices in public universities. In this era of globalisation where the university is held accountable for societal development through the quality of graduate they produced, it is imperative for the policymakers to create courses that will incorporate complex and multi-dimensional activities to develop the universities leaders at every level of the organisation. This will help the university leader to identify the staffs' strength, provide opportunities for lecturers in taking up leadership roles in their areas of expertise, as well as building a collegial community that will embrace a shared vision, utilising data to improve instruction and relying on the academic staffs to effectively assume a decision-making role.

Even though many studies applied the qualitative approach, the method of qualitative design applied for this study which is considered generic inquiry qualitative method is also very important as it is not commonly found in educational leadership or performance management research. As such, it makes a theoretical contribution to educational leadership studies.

\section{CONCLUSION}

This study has revealed the prevalent issues of factors inhibiting the effectiveness of public universities in Nigeria. This include, leadership issues, funding, contextual issues in terms of ethnicity, corruption and security as well as leadership issues. Therefore, for the university system to plays its role towards the training of competent workforce for other sectors of the economy, the identifies issues must be addressed to its barest minimum. Furthermore, this study interviews the lecturers and academic administrators which are referred to as the leading players in university education. However, the voice of other stakeholders could also be examined in a future study.

\section{REFERENCES}

Adeboyeje, T. (2003). Disruption, violence and productivity in Nigerian universities. Nigerian Journal of Educational Administration and Planning, 4(1), 21-25.

Adeogun, A. A. (2006). Training and experience as predictors of teachers' productivity in secondary schools in Nigeria. International Journal of Educational Management, 4(1), 38-49.

Adetunji, A. T. (2015). Quality issues: Beyond the Nigerian institution. International Journal of Research Studies in Management, 4(2), 3-12.

Agabi, O., Obasi, K., \& Ohia, A. (2012). Academic programme development and the participation of relevant interest groups for quality manpower production in Nigeria higher education. World Journal of Education, 2(3), 87-93.

Arjomandi, M., Kestell, C., \& Grimshaw, P. (2009). An EFQM Excellence Model for higher education quality assessment. Paper presented at the Proceedings of the 20th AAEE Australasian Association for Engineering Education Conference: Engineering the Curriculum.

Asiyai, R. I. (2006). Variables inducing trade union disputes in Nigerian Universities. Nigerian Journal of Guidance and Counselling, 11(1), 146-155.

Asiyai, R. I. (2013). Challenges of quality higher education in Nigeria in the 21st century. International Journal of Educational Planning and Administration, 3(2), 159-172. 


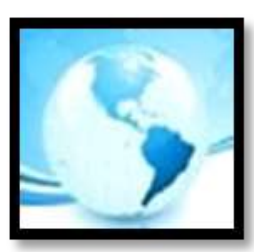

\section{MALAYSIAN ONLINE JOURNAL OF EDUCATIONAL MANAGEMENT (MOJEM)}

Becket, N., \& Brookes, M. (2008). Quality management practice in higher education: What quality are we actually enhancing. Journal of Hospitality, Leisure, Sport \& Tourism Education, 7(1), 40-54.

Caelli, K., Ray, L., \& Mill, J. (2003). Clear as mud: Toward greater clarity in generic qualitative research. International Journal of Qualitative Methods, 2(2), 1-13.

Calvo-Mora, A., Leal, A., \& Roldán, J. L. (2006). Using enablers of the EFQM model to manage institutions of higher education. Quality Assurance in Education, 14(2), 99-122. doi: 10.1108/09684880610662006.

Cameron, K. (1978). Measuring organizational effectiveness in institutions of higher education. Administrative Science Quarterly, 23(4), 604-632.

Chua, C. (2004). Perception of quality in higher education. Paper presented at the Australian Universities Quality Forum, Melbourne, 7-9 July.

Claver, E., \& Tarí, J. J. (2008). The individual effects of total quality management on customers, people and society results and quality performance in SMEs. Quality and Reliability Engineering International, 24(2), $199-211$.

Cohen, L., Manion, L., \& Morrison, K. (2011). Research methods in education. England: Routledge.

Creswell, J. W. (2012). Qualitative inquiry and research design: Choosing among five approaches. London: SAGE.

Cruz, W. S. D. (2011). The roles of organizational culture, management strategy, and decision-making process on institutional effectiveness at a four-year public higher education institution. San Antonio: University of Texas.

Daly, J., Kellehear, A., \& Gliksman, M. (1997). The Public Health Researcher: A Methodological Approach. Melbourne: Oxford University Press.

Darma, M. R. (2013). Enhancing teaching, research in Nigerian universities: The PTDF initiative. Leadership Newspaper, p. 6-7. Retrieved from http://leadership.com.ng/nga/columns/348/2011/06/01/ enhancing_teaching_research_nigerian_universities_ptdf_initiative.html?quicktabs_3=1

Davies, J., Hides, M., \& Casey, S. (2001). Leadership in higher education. Total Quality Management, 12(7-8), 10251030.

Dung, T. T. M. (2014). Exploring challenges of middle leadership in higher education: A case study of a Vietnamese university. Malaysian Online Journal of Educational Management, 2(3), 70-96.

European Foundation for Quality Management. (2012). Structured approach to questioning the performance on an organisation. Retrieved from http://www.efqm.org/efqm-model/radar-logic

European Foundation for Quality Management. (2013). Model criteria. Retrieved from http://www.efqm.org/efqm-model/model-criteria.

Ekundayo, H., \& Ajayi, I. (2009). Towards effective management of university education in Nigeria. International NGO Journal, 4(8), 342-347.

Francis, D.-A. I. (2015). Solving the problem of poor quality of university graduates in Nigeria: A proposed holistic approach. British Journal of Education, 3(7), 52-70. 


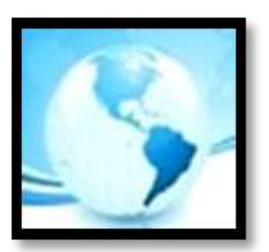

\section{MALAYSIAN ONLINE JOURNAL OF EDUCATIONAL MANAGEMENT (MOJEM)}

Federal Republic of Nigeria. (2004). National Policy on Education. Lagos: Nigerian Educational Research and Development Council Press.

Hides, M. T., Davies, J., \& Jackson, S. (2004). Implementation of EFQM excellence model self-assessment in the UK higher education sector-lessons learned from other sectors. The TQM Magazine, 16(3), 194-201.

Huitt, W. (2003). A transactional model of the teaching/learning process. Educational Psychology Interactive. Valdosta, GA: Valdosta State University. Retrieved from http://www.edpsycinteractive.org/materials/tchlrnmd.html.

Idumange, J. A., \& Chukwuemeka, N. G. (2009). Marketization of university education in Nigeria: Implications for access and equity. Multidisciplinary Journal of Research Development, 12(1), 136-143.

Kaffashpoor, A. (2013). Linking organizational culture, structure, leadership style, strategy, and organizational effectiveness: Mediating role of knowledge management. Advanced Research in Economic and Management Sciences, 10, 158-172.

Kahlke, R. M. (2014). Generic qualitative approaches: Pitfalls and benefits of methodological mixology. International Journal of Qualitative Methods, 13(1), 37-52.

Kayode, D. J. (2016). Relationship between distributed leadership, quality administrative and academic processes and institutional effectiveness in public universities in Nigeria. (Unpublished doctoral thesis), Universiti Utara Malaysia, Malaysia.

Kayode, D. J., Oduwaiye, R. O., Etejere, P. A., Sheu, A. A., \& Kutu, J. O. (2018). Quality academic process: A panacea for student development in university education. Journal of Quantitative Methods ,2(1), 63-87.

Kayode, D. J., Yusoff, N. M., Veloo, A., Oduwaiye, R. O., \& Sheu, A. A. (2018). An investigation into lecturers' perceptions about distributed leadership in public universities in Nigeria. Journal of Arts and Social Sciences, 4(1), 1-25.

Kpee, G. G., Oluwuo, S. O., \& Baridam, D. (2012). Academic renewal and relevance in south-south Nigerian universities: Curriculum prospects and challenges. Global Voice of Educators, 1(1), 1-8.

Krueger, N. F. (2007). The cognitive infrastructure of opportunity emergence. Entrepreneurship: Theory and practice. In A. Cuero, D. Ribeiro, \& S. Roid (Eds.). Entrepreneurship: Concepts, theory and perspective, (pp. 185-206). New York: Springer.

Iordache-Platis, M. (2019, May). Wellbeing in universities and Romanian quality assurance requirements; possible university strategy. In Proceedings of the International Conference on Business Excellence, 13(1), 10871097.

Malone, P. (2003). Institutional effectiveness practices in colleges and universities in the Southeastern United States (Published Doctoral dissertation). Florida State University: Tallahassee. Retrieved from http://eserv.uum.edu.my/docview/305325883 ?accountid=42599.

Marshall, C., \& Gretchen, B. R. (2014). Designing qualitative research. Thousand Oaks, CA: Sage Publications. 


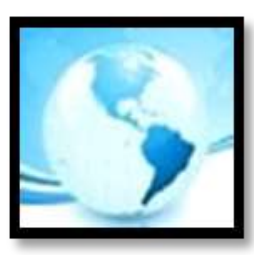

\section{MALAYSIAN ONLINE JOURNAL OF EDUCATIONAL MANAGEMENT (MOJEM)}

Mathieu, C., \& Babiak, P. (2015). Tell me who you are, I'll tell you how you lead: Beyond the full-range leadership model, the role of corporate psychopathy on employee attitudes. Personality and Individual Differences, 87(2015), 8-12. doi: http://dx.doi.org/10.1016/j.paid.2015.07.016.

Morrison, K. (2010). Complexity theory, school leadership and management: Questions for theory and practice. Educational Management Administration \& Leadership, 38(3), 374-393.

Nichols, J. O. (1989). Institutional effectiveness and outcomes assessment implementation on campus: a practitioner's handbook. New York: Agathon Press.

Nir, A. E., \& Zilberstein-Levy, R. (2006). Planning for academic excellence: Tenure and professional considerations. Studies in Higher Education, 31(5), 537-554. doi:10.1080/03075070600922725.

Nkang, I. E. (2013). Challenges of globalization and quality assurance in Nigerian university education. International Education Studies, 6(1), 207-215.

National University Commission. (2004). Labour market expectations of Nigeria graduates. Ibadan: Heinemann Educational Nig.

National University Commission. (2012). Universities' accreditation report 2012. Abuja: NUC Press.

Okebukola, P. (2005). Quality assurance in the Nigerian university system. Paper presented at the A key note address presented at the 2005 fellowship seminar/award of the Curriculum Organisation of Nigeria held at Bauchi Road Campus, University of Jos, Jos Nigeria.

Okojie, J. (2013). Why Nigerian graduates are not employable. Punch Newspaper, p. 5-6. http://www.punchng.com/news/why-nigerian-graduates-are-not-employable-okojie/

Okonkwo, U., Ubani, N., \& Ubachukwu, O. (2013). A functional curriculum for engineering education in Nigerian Universities. International Journal of Scientific \& Engineering Research, 4(1), 1-5.

Olasehinde-Williams, F. O. (2012). Without wax: Re-formatting the education system. 112th Inaugural lecturers delivered at University of Ilorin (6 $6^{\text {th }}$ October, 2012). Ilorin: Unilorin Press.

Olorundare, A. S., \& Kayode, D. J. (2014). Entrepreneurship education in Nigerian universities: A tool for national transformation. Asia Pacific Journal of Educators and Education, 29, 155-175.

Onoyase, D., \& Onoyase, A. (2005). Effective strategies for the management of cultism in institutions of higher learning in Nigeria. The Nigerian Academic Forum, 12(3), 19-24.

Onwuegbuzie, A. J., \& Collins, K. M. (2007). A typology of mixed methods sampling designs in social science research. The Qualitative Report, 12(2), 281-316.

Oyebade, S. A., Oladipo, S. A., \& Adetoro, J. A. (2008). Determinants and strategies for quality assurance in Nigerian university education. Lagos: Herpnet. Retrieved from http://herp-net.org.

Percy, W. H., Kostere, K., \& Kostere, S. (2015). Generic qualitative research in psychology. The Qualitative Report, 20(2), 76-85. 
Seo, G. (2013). Challenges in implementing enterprise resource planning (ERP) system in large organizations: similarities and differences between corporate and university environment (Unpublished Doctoral dissertation), Massachusetts Institute of Technology, Massachusetts.

Serban, A. M. (2007). Assessing organizational performances in higher education. Journal of Applied Research in the Community College, 15(1), 87-88.

Suter, W. N. (2012). Introduction to educational research: A critical thinking approach. London: Sage.

Tabish, S., \& Syed, N. (2015). Towards establishing world-class universities: A conceptual approach. International Journal of Science and Research, 4(2), 614-633.

Tarí, J. J. (2008). Self-assessment exercises: A comparison between a private sector organisation and higher education institutions. International Journal of Production Economics, 114(1), 105-118.

Tarí, J. J., \& Madeleine, C. (2012). Introducing management models in service organisations in developed and developing countries. The Service Industries Journal, 32(5), 789-806.

Uche, R. D. (2014). Students' perception of corrupt practices among Nigerian Universities lecturers. American Journal of Humanities and Social Sciences, 2(1), 66-69.

Vihma, A. (2007). Institutional effectiveness of global climate governance. Paper presented at the 2007 Master Class of Amsterdam conference of Human Dimensions of Global Environmental Change (IHDP). 24-26.

Voss, R., Gruber, T., \& Szmigin, I. (2007). Service quality in higher education: The role of student expectations. Journal of Business Research, 60(9), 949-959. doi: http://dx.doi.org/10.1016/j.jbusres.2007.01.020. 